\title{
Research Article \\ Effect of Wood Preservatives on Surface Properties of Coated Wood
}

\author{
Turgay Ozdemir, Ali Temiz, and Ismail Aydin \\ Department of Forest Industry Engineering, Faculty of Forestry, Karadeniz Technical University, 61080 Trabzon, Turkey \\ Correspondence should be addressed to Turgay Ozdemir; turgay@ktu.edu.tr
}

Received 17 April 2015; Revised 21 June 2015; Accepted 23 June 2015

Academic Editor: Simon C. Potter

Copyright (C) 2015 Turgay Ozdemir et al. This is an open access article distributed under the Creative Commons Attribution License, which permits unrestricted use, distribution, and reproduction in any medium, provided the original work is properly cited.

\begin{abstract}
Effect of wood preservatives (waterborne and organicborne) on the performance of surface finishing properties is investigated. Sapwood of scots pine, (Pinus sylvestris L.), oriental beech (Fagus orientalis Lipsky), and chestnut (Castanea sativa Mill.) specimens $(300 \times 100 \times 15 \mathrm{~mm}$ along the grain) were impregnated with aqueous solution of $2 \%$ CCA, $2 \%$ Tanalith E, $1 \%$ boric acid, and Immersol aqua. Surface roughness, dry film thickness, adhesion strength, gloss measurement, scratch, and abrasion resistance were determined according to related standards for treated and untreated samples. The results indicated that surface roughness and adhesion strength depended on wood species and the chemical composition of preservatives. Generally, waterborne wood preservatives increased the surface roughness of wood while the organic-based wood preservatives decreased it. The organic-based wood preservatives decreased adhesion but they increased gloss value. Wood preservatives did not affect the scratch resistance which was found to depend on properties of the coating. All the wood preservatives increased abrasion resistance.
\end{abstract}

\section{Introduction}

Wood and wood-based materials have gained extensive usage areas in outdoor and indoor applications due to their abundance and versatility. Wood, commonly used in outdoor applications, is preferred for proper protection and best service life against decay (rot), insects, weathering, and dimensional instability $[1,2]$. The term of wood weathering describes combination of UV-degradation, moisture, heat, and atmospheric pollutants (e.g., acid rain, ozone, nitrogen oxides, and sulphur dioxide) [3]. Wood has several chromophoric functional groups and sites such as hydroxyl, carbonyl, carboxyl groups, and aromatic and phenolic groups [3]. The effect of wood weathering is manifested by initial wood surface colour changes, followed by loss of gloss, roughening, and checking $[1,3]$. These changes are due to modification of chromophoric groups of wood and formation of coloured quinines-like component [1, 3, 4].

Wood materials can be protected against these factors by applying wood treatment process and/or wood finishing. The first option is the treatment with wood preservatives. The major wood preservatives used for treatment process are creosote, pentachlorophenol, CCA (chromated copper arsenate), and other copper-based wood preservatives such as alkaline copper quaternary (ACQ) and amine copper azole (CA) $[1,2,5]$.

The second option is applying coatings. A variety of finishes or coatings can be applied to wood. Finishes can be divided into two groups: (1) opaque coatings, such as paints and solid-color stains and (2) natural finishes, such as water repellents, oils, and semitransparent penetrating stains [6]. Performance of wood coatings depends on several factors such as wooden substrate itself, humidity, moisture content of wood, temperature, environmental pollutants, and microorganisms [7]. Photo-induced degradation of wood caused shorter service life of wood coatings. This is due to penetration of UV light through transparent finishes and degradation of the bonding mechanism between finishes and wood [7]. The performance of wood coatings can be improved by different strategies. One option is to add UV absorbers and radical scavengers. The second strategy is treatment of wood materials with wood preservatives since wood preservatives can inhibit photo-induced degradation and increase durability against fungi and insects [7]. The most common wood preservative used is the chromated copper arsenate (CCA) but it contains pentavalent arsenic 
which is hazardous to human and environment [2]. The effect of chromated copper arsenate (CCA) on the wood weathering and its combination with the wood coatings are well-established $[3,8]$. However, there is still research needed on the performance of new generation preservatives which are copper based but chrome- and arsenic-free.

In this study, it was aimed at determining the effect of new generation wood preservatives on the performance of wood coating. Scots pine, beech, and chestnut samples were treated with CCA, Tanalith E, boric acid, and Immersol and coated with cellulosic-based finishing.

\section{Material and Methods}

2.1. Treatment Process. Sapwood of scots pine, (Pinus sylvestris L.), oriental beech (Fagus orientalis Lipsky), and chestnut (Castanea sativa Mill.) specimens $(300 \times 100 \times 15 \mathrm{~mm}$ along the grain) were impregnated with aqueous solution of $2 \%$ CCA, 2\% Tanalith E, and 1\% boric acid and Immersol aqua vacuum ( $625 \mathrm{~mm} \mathrm{Hg}$ ) over the blocks was applied for $45 \mathrm{~min}$. After vacuum, the wood samples were kept in the treatment solution for $60 \mathrm{~min}$ in atmospheric conditions. The wood samples were then removed from the treatment solution, wiped lightly to remove solution from the wood surface, and weighed to determine gross retentions for sample. Retention values were chosen according to producers' suggestions. The retention for each treatment solution was calculated according to the following formula:

$$
R=\left(\frac{(G \times C)}{V}\right) \times 10 \mathrm{Kg} / \mathrm{m}^{3}
$$

where

$G$ are the grams of treating solution absorbed by the block,

$C$ are grams of preservative or preservative solution in $100 \mathrm{~g}$ of the treating solution,

$V$ is volume of block in cubic centimeters.

After the treatment process, the samples treated with copper-based wood preservatives were then wrapped in plastic bag for a week at the room temperature for fixation.

2.2. Surface Coating Process. The surfaces of the samples were sanded with 100 and then with 150 grid size sandpaper. Cellulose varnish type was commercially obtained from supplier. The coating was applied by spraying with approximate varnish application amount of $120 \mathrm{~g} / \mathrm{m}^{2}$. Viscosity for application was $20 \mathrm{~s}$, DIN cup $/ 4 \mathrm{~mm} / 20^{\circ} \mathrm{C}$. The coating was applied to surface as 2 bases and 1 top layer. The component details of the coatings used are given in Table 1.

2.3. Surface Roughness. Surface roughness values of the treated and untreated samples were determined by using Mitutoyo Surftest SJ-301, a stylus type profilometer. Detector tip radius was $5 \mu \mathrm{m}$ while cut-off length was $2.5 \mathrm{~mm}$ and sampling length was $12.5 \mathrm{~mm}$ in the surface roughness measurements. Three roughness parameters including the
TABLE 1: Mixture portion of coatings.

\begin{tabular}{lccc}
\hline Varnish variety & $\begin{array}{c}\text { Varnish } \\
\text { (portion) }\end{array}$ & $\begin{array}{c}\text { Hardener } \\
\text { (portion) }\end{array}$ & $\begin{array}{c}\text { Thinner } \\
\text { (portion) }\end{array}$ \\
\hline Cellulosic primer coat & 100 & - & 80 \\
Cellulosic top coat & 100 & - & 80 \\
\hline
\end{tabular}

average roughness $\left(R_{a}\right)$, the mean peak-to-valley height $\left(R_{z}\right)$, and the maximum roughness $\left(R_{\max }\right)$ were used to evaluate surface roughness of the samples according to DIN 4768 [9]. A total of fifteen replicate measurements were taken from each untreated and treated wood. The dimensions of specimens used for surfaces roughness measurements were $10 \mathrm{~cm}$ by $10 \mathrm{~cm}$. All measurements were made across the grain orientation.

2.4. Dry Film Thickness. Dry coating thickness of samples treated wood preservatives and untreated (control) was determined by using the dry film thickness apparatus (Erichsen P.I.G 455) according to ASTM D 4138 [10].

2.5. Adhesion Strength. Adhesion strength based on the Pulloff methods was determined according to ASTM D 4541 [11]. Twenty different points with a contact area of $20 \mathrm{~mm}$ circles were taken from each side of the treated and untreated samples. The Ericksen Adhesion-525 MC tester with a head glued to the surface of the samples was employed for the test. The testing device runs at a constant speed of $10 \mathrm{~cm} / \mathrm{min}$ and applies tension force to the surface layer by pulling the coating from the wood surface.

2.6. Gloss Measurement. Gloss measurement was carried out according to standard test of ISO 2813 [12]. Ten replicates with dimensions of 100 by 100 by $15 \mathrm{~mm}$ were used. During the measurements, the $60^{\circ}$ geometry was applied to all coated samples.

2.7. Scratch Resistance. Scratch resistance test was done according to DIN 68861 [13]. Rotation was $5 \mathrm{r} / \mathrm{min} \pm 1 \mathrm{r} / \mathrm{min}$. A special scratch diamond with a hemispherical point was used with different weight forces $(1.5-4.0 \mathrm{~N})$. Five replicates $(100 \times 100 \times 15 \mathrm{~mm})$ for each group were used for determining the resistance of scratch.

2.8. Abrasion Resistance. Abrasion test was carried out according to DIN 68861 [14]. In this test, the taber abraser consists of a horizontal plate on which the test samples with the dimensions of 100 by 100 by $15 \mathrm{~mm}$ were placed flat. Five replicates were used. The plate turned at a speed of $55 \pm$ $6 \mathrm{~min}^{-1}$. Above the plate, two abrasive discs with rubber coating were mounted to a press that can exert a force of $5.5 \pm$ 0.2 onto the test piece. Strips of sandpaper were attached to the rubber coating. The number of revolutions necessary to reach the final point then determines the abrasion as follows:

(a) Meaning up to $50 \%$ of the wood has been worn away.

(b) In case of self-colored surface, the color disappears, and/or the under surface was visible. 
TABLE 2: Average retention and surface roughness results of untreated and treated samples.

\begin{tabular}{|c|c|c|c|c|c|c|c|c|c|c|c|c|}
\hline & \multicolumn{4}{|c|}{ Pine } & \multicolumn{4}{|c|}{ Beech } & \multicolumn{4}{|c|}{ Chestnut } \\
\hline & $\begin{array}{c}R_{a} \\
{[\mu \mathrm{m}]}\end{array}$ & $\begin{array}{l}R_{\max } \\
{[\mu \mathrm{m}]}\end{array}$ & $\begin{array}{c}R_{z} \\
{[\mu \mathrm{m}]}\end{array}$ & $\begin{array}{c}\text { Retention } \\
\left(\mathrm{kg} / \mathrm{m}^{3}\right)\end{array}$ & $R_{a}$ & $R_{\max }$ & $R_{z}$ & $\begin{array}{c}\text { Retention } \\
\left(\mathrm{kg} / \mathrm{m}^{3}\right)\end{array}$ & $R_{a}$ & $R_{\max }$ & $R_{z}$ & $\begin{array}{c}\text { Retention } \\
\left(\mathrm{kg} / \mathrm{m}^{3}\right)\end{array}$ \\
\hline $\begin{array}{l}\text { Untreated } \\
\text { (Control) }\end{array}$ & $\begin{array}{c}2.67 \\
(0.94)^{*} \\
\end{array}$ & $\begin{array}{c}27.13 \\
(11.62) \\
\end{array}$ & $\begin{array}{c}21.82 \\
(8.42) \\
\end{array}$ & - & $\begin{array}{c}2.87 \\
(0.90) \\
\end{array}$ & $\begin{array}{l}32.97 \\
(11.18) \\
\end{array}$ & $\begin{array}{c}25.31 \\
(6.74) \\
\end{array}$ & - & $\begin{array}{l}5.44 \\
(1.12) \\
\end{array}$ & $\begin{array}{c}82.41 \\
(14.40) \\
\end{array}$ & $\begin{array}{c}55.31 \\
(14.49) \\
\end{array}$ & - \\
\hline $2 \%$ CCA & $\begin{array}{c}3.25 \\
(0.70) \\
\end{array}$ & $\begin{array}{c}35.74 \\
(13.33) \\
\end{array}$ & $\begin{array}{c}27.21 \\
(6.43) \\
\end{array}$ & $\begin{array}{l}15.67 \\
(0.78) \\
\end{array}$ & $\begin{array}{c}4.74 \\
(1.38) \\
\end{array}$ & $\begin{array}{l}42.73 \\
(9.91) \\
\end{array}$ & $\begin{array}{c}37.39 \\
(8.49) \\
\end{array}$ & $\begin{array}{c}13.28 \\
(0.66) \\
\end{array}$ & $\begin{array}{c}6.20 \\
(1.52) \\
\end{array}$ & $\begin{array}{c}90.54 \\
(17.1)\end{array}$ & $\begin{array}{l}59.02 \\
(16.1)\end{array}$ & $\begin{array}{l}10.25 \\
(0.52)\end{array}$ \\
\hline $2 \%$ Tanalith E & $\begin{array}{c}3.28 \\
(0.98)\end{array}$ & $\begin{array}{l}29.26 \\
(9.15)\end{array}$ & $\begin{array}{c}24.61 \\
(6.09)\end{array}$ & $\begin{array}{l}15.39 \\
(0.56)\end{array}$ & $\begin{array}{c}3.75 \\
(1.32)\end{array}$ & $\begin{array}{l}38.60 \\
(11.48)\end{array}$ & $\begin{array}{c}31.39 \\
(6.69)\end{array}$ & $\begin{array}{l}12.01 \\
(0.45)\end{array}$ & $\begin{array}{c}5.92 \\
(1.15)\end{array}$ & $\begin{array}{l}106.05 \\
(19.28)\end{array}$ & $\begin{array}{l}57.31 \\
(7.89)\end{array}$ & $\begin{array}{l}10.36 \\
(0.78)\end{array}$ \\
\hline $1 \%$ Boric acid & $\begin{array}{c}2.86 \\
(0.60)\end{array}$ & $\begin{array}{l}28.41 \\
(7.12)\end{array}$ & $\begin{array}{c}24.12 \\
(4.75)\end{array}$ & $\begin{array}{c}6.92 \\
(0.34)\end{array}$ & $\begin{array}{c}3.45 \\
(0.97)\end{array}$ & $\begin{array}{l}33.01 \\
(7.69)\end{array}$ & $\begin{array}{l}29.23 \\
(6.65)\end{array}$ & $\begin{array}{c}5.77 \\
(0.36)\end{array}$ & $\begin{array}{c}9.38 \\
(2.73)\end{array}$ & $\begin{array}{l}106.42 \\
(19.91)\end{array}$ & $\begin{array}{c}77.37 \\
(22.30)\end{array}$ & $\begin{array}{c}5.14 \\
(0.28)\end{array}$ \\
\hline Immersol aqua & $\begin{array}{c}1.92 \\
(0.32)\end{array}$ & $\begin{array}{l}20.43 \\
(8.17)\end{array}$ & $\begin{array}{l}16.44 \\
(5.07)\end{array}$ & $\begin{array}{l}715.96 \\
(37.64)\end{array}$ & $\begin{array}{c}1.99 \\
(0.55)\end{array}$ & $\begin{array}{l}19.88 \\
(5.57)\end{array}$ & $\begin{array}{l}18.27 \\
(4.31)\end{array}$ & $\begin{array}{c}481.83 \\
(25.96)\end{array}$ & $\begin{array}{c}7.53 \\
(1.84)\end{array}$ & $\begin{array}{l}67.92 \\
(8.13)\end{array}$ & $\begin{array}{l}54.30 \\
(9.48)\end{array}$ & $\begin{array}{c}377.49 \\
(20.69)\end{array}$ \\
\hline
\end{tabular}

*Values in parenthesis are standard deviations.

2.9. Statistical Analysis. The multifactor analysis of variance was used for comparing the results obtained from experiments. The Duncan test with 95\% confidence level was used to compare mean values of variance sources.

\section{Result and Discussion}

The average retention and surface roughness values of pine, beech, and chestnut wood samples treated with CCA, Tanalith E, boric acid, and Immersol aqua are presented in Table 2.

According to Table 2, the surfaces of pine control samples were found to be smoother than those of beech and chestnut control samples. The surface roughness differences between pine wood as softwood and beech and chestnut woods as hardwoods could be related to their density differences [15]. Among hardwoods, chestnut samples showed higher surface roughness than beech wood. Chestnut is ring-porous tree while beech wood is diffuse-porous tree. Therefore, vessels in chestnut tree are located mainly in earlywood section which causes higher surface roughness while vessels in beech wood are located throughout cross section which causes smother surface.

The highest average surface roughness value $\left(R_{z}\right)$ was measured on chestnut samples treated with boric acid $(77.37 \mu \mathrm{m})$ and the lowest result was obtained for pine samples treated with solvent-based wood preservative $(16.44 \mu \mathrm{m})$. Generally, waterborne wood preservatives increased surface roughness of wood. While, organic-based ones decreased it (Table 3 ).

Effects of wood preservatives on the surface roughness of wood depend on wood species and wood preservative types used due to anatomical differences between softwood and hardwood, wood preservatives' chemical composition, and bonding mechanism with wood. It was reported that waterborne wood preservatives increased surface roughness of wood due to increased surface porosity and raised fibres on the surface of wood. However, organicborne wood preservatives decreased surface roughness of wood due to the filled surface cavity and decreased surface porosity [16].
The highest surface roughness value is obtained for samples treated with boric acid $\left(R_{z}=43.57 \mu \mathrm{m}\right)$ since boric acid crystals were formed on the wood surfaces after impregnation [17].

According to a study conducted by Maldas and Kamdem [18], the surface of CCA-treated red maple wood was found to be rougher than that of untreated wood. However, no marked changes in the surface roughness of alder and beech wood after borax and boric acid treatment were found by Aydin and Colakoglu [19]. Temiz et al. [20] also reported that impregnation with copper-based preservatives (CCA, ACQ, Tanalith E, and Wolmanit CX) increased the values of surface roughness when compared with untreated (control) samples.

Table 3 shows statistically the effects of wood species and wood preservatives on finishing properties.

Dry film thickness of treated and untreated wood species was found as $90 \mu \mathrm{m}$ for all group and wood species. No differences were found between untreated and treated wood samples. These results agreed with those obtained by others $[16,21-23]$.

Figures 1 and 2 illustrate the effect of treatment on adhesion strength and gloss values.

The highest adhesion strengths were determined on beech-treated and beech-untreated wood samples while the lowest adhesion strength was obtained on pine samples. These differences can be attributed to wood properties and density differences (higher density of beech wood). Beech wood which has diffuse-porous structure showed better absorption of the varnish, which, in turn, caused higher magnitude of interaction between wood and varnishes. In addition, varnishes applied on beech and chestnut samples had deeper penetration than that of pine samples due to their more porous structures. Similar findings were reported by previous studies $[24,25]$. According to the adhesion strength test, organic-based wood preservative showed the lowest adhesion result among the other wood preservatives due to decreasing bonding capacity of coatings and wood. However, boric acid treatment provided increasing adhesion strength for all wood species used. The increasing adhesion strength of boric acid treatment could be attributed to higher mechanical 
TABLE 3: Statistical results of Duncan test.

\begin{tabular}{|c|c|c|c|}
\hline Properties & Factors & LS mean & $\begin{array}{c}\text { Homogenous } \\
\text { groups }\end{array}$ \\
\hline \multirow{10}{*}{$\begin{array}{l}\text { Surface } \\
\text { roughness } \\
\left(R_{z}\right)\end{array}$} & Wood species & & \\
\hline & Pine & 22.83 & $\mathrm{a}$ \\
\hline & Beech & 26.45 & $\mathrm{~b}$ \\
\hline & Chestnut & 60.66 & c \\
\hline & Treatment & & \\
\hline & Untreated & 34.54 & $\mathrm{~b}$ \\
\hline & CCA & 37.70 & $\mathrm{~b}$ \\
\hline & Tanalith E & 37.77 & $\mathrm{~b}$ \\
\hline & Boric acid & 43.57 & c \\
\hline & Solvent & 29.67 & $\mathrm{a}$ \\
\hline \multirow{10}{*}{$\begin{array}{l}\text { Adhesion } \\
\text { strength }\end{array}$} & Wood species & & \\
\hline & Pine & 1.44 & $\mathrm{a}$ \\
\hline & Beech & 2.64 & $\mathrm{~b}$ \\
\hline & Chestnut & 2.03 & c \\
\hline & Treatment & & \\
\hline & Untreated & 2.22 & c \\
\hline & CCA & 1.98 & $\mathrm{~b}$ \\
\hline & Tanalith E & 2.02 & $\mathrm{~b}$ \\
\hline & Boric acid & 2.38 & $\mathrm{~d}$ \\
\hline & Solvent & 1.60 & $\mathrm{a}$ \\
\hline \multirow{10}{*}{ Gloss } & Wood species & & \\
\hline & Pine & 49.65 & a \\
\hline & Beech & 48.97 & a \\
\hline & Chestnut & 52.27 & $\mathrm{~b}$ \\
\hline & Treatment & & \\
\hline & Untreated & 54.15 & $\mathrm{~b}$ \\
\hline & CCA & 45.95 & $\mathrm{a}$ \\
\hline & Tanalith E & 46.32 & $\mathrm{a}$ \\
\hline & Boric acid & 45.02 & a \\
\hline & Solvent & 60.04 & $\mathrm{c}$ \\
\hline \multirow{10}{*}{$\begin{array}{l}\text { Abrasion } \\
\text { resistance }\end{array}$} & Wood species & & \\
\hline & Pine & 35.86 & a \\
\hline & Beech & 41.13 & b \\
\hline & Chestnut & 47.73 & c \\
\hline & Treatment & & \\
\hline & Untreated & 35.44 & a \\
\hline & CCA & 47.16 & d \\
\hline & Tanalith E & 43.83 & c \\
\hline & Boric acid & 40.33 & $\mathrm{~b}$ \\
\hline & Solvent & 41.11 & $\mathrm{bc}$ \\
\hline \multirow{10}{*}{$\begin{array}{l}\text { Scratch } \\
\text { resistance }\end{array}$} & Wood species & & \\
\hline & Pine & 0.49 & $\mathrm{a}$ \\
\hline & Beech & 0.51 & $\mathrm{a}$ \\
\hline & Chestnut & 0.50 & $\mathrm{a}$ \\
\hline & Treatment & & \\
\hline & Untreated & 0.51 & a \\
\hline & CCA & 0.46 & a \\
\hline & Tanalith E & 0.49 & a \\
\hline & Boric acid & 0.50 & $\mathrm{a}$ \\
\hline & Solvent & 0.50 & $\mathrm{a}$ \\
\hline
\end{tabular}

${ }^{*}$ Different letters denote a statistically significant difference.

interlocking mechanism of adhesion caused by increased surface roughness of boric acid-treated wood.

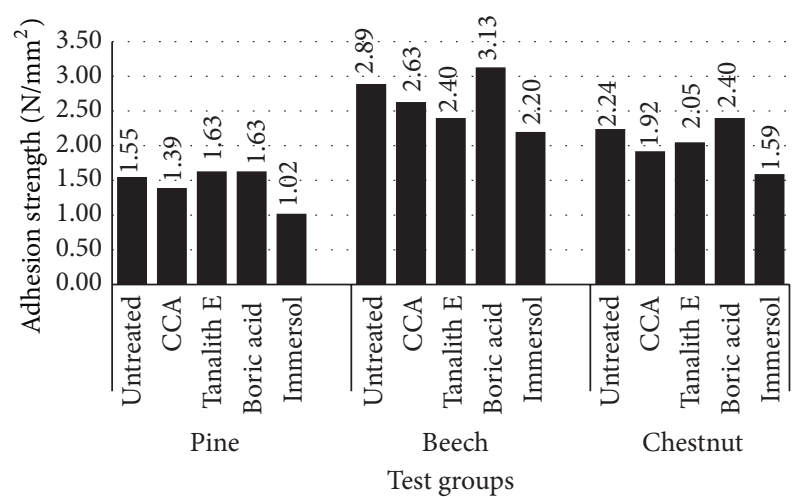

FIGURE 1: Adhesion strength of untreated and treated samples.

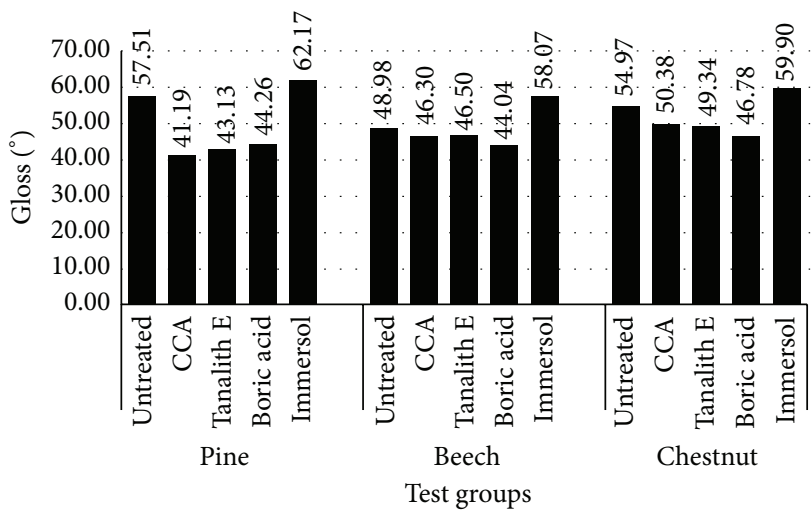

FIGURE 2: Gloss values of untreated and treated samples.

The decreasing adhesion test for treated samples could be related to poor wetting properties after impregnation. The fact that the poor wettability resulted in poor adhesion was also observed by Gray [26], Shupe et al. [27], and Aydin [28]. Poor wettability for CCA-treated wood was also reported by Maldas and Kamdem [18].

The highest value of the gloss measurement was determined on organic-based wood preservative treatment. The waterborne wood preservatives of control groups (untreated) decreased gloss values while organic-based wood preservative increased them. The reason for higher gloss value of organicborne wood preservative could be better filled surface cavity that resulted in better reflection of light. However, water-based wood preservatives increased surface porosity and raised fibres decreased gloss value. Regarding to wood species, pine untreated samples showed highest gloss value while the lowest gloss value was obtained for beech-untreated samples. The differences between gloss values are due to the anatomical and chemical structure of softwood and hardwoods.

The scratch resistance and the abrasion resistance of the untreated and treated samples are shown in Figures 3 and 4.

As expected, there were no major differences between wood species and treatment preservatives because scratch resistance depended on only properties of the coating, that is, components, hardness of coating film, and so forth (Table 3 ). Similar findings were reported by other researchers $[22,29]$. 


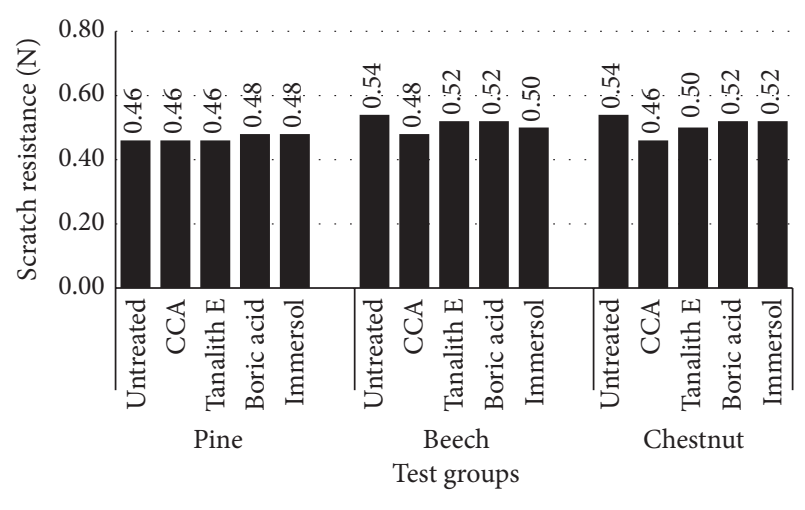

Figure 3: Scratch resistance of untreated and treated samples.

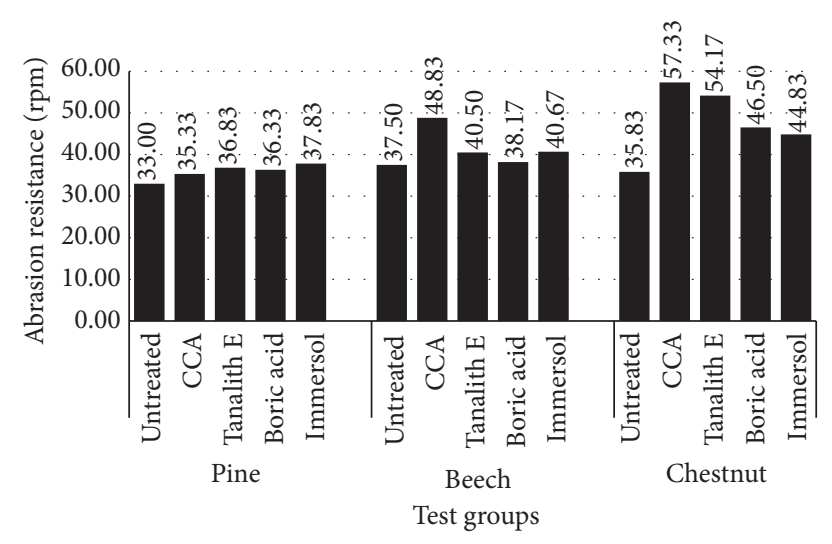

FIGURE 4: Abrasion resistance of untreated and treated samples.

Regarding to the abrasion resistance test the untreated beech samples had higher abrasion resistance values $(37.50 \mathrm{rpm})$ than those of the untreated pine $(33.00 \mathrm{rpm})$ and chestnut $(35.83 \mathrm{rpm})$. This is due to the wood properties such as density and permeability. Wood preservatives increased abrasion resistance for all groups. Remaining film layer on the surface caused to an increase in the abrasion resistance.

\section{Conclusions}

This study dealt with the effect of wood preservatives on the performance of finishing. Waterborne and organic-based wood preservatives were tested. The major findings of the study can be listed as follows:

(1) Surface roughness values changed depending on wood species due to the anatomical differences between softwood and hardwood.

(2) Adhesion properties of treated wood depended on the chemical composition of preservatives. Organicbased wood preservative (Immersol aqua) decreased the adhesion properties because of the poor adhesion properties after impregnation. While organic-based wood preservative increased the gloss value, the waterborne wood preservatives decreased the gloss value.
(3) Wood preservatives did not affect the scratch resistance which was disclosed to depend on the coating properties.

(4) Treatment with both waterborne and organic-based wood preservatives increased the abrasion strength significantly.

\section{Disclosure}

Some part of this study was presented in International Research Group of Wood Protection Annual Meeting at Istanbul, Turkey, in 2008 (IRG-WP 08-40405).

\section{Conflict of Interests}

The authors declare that there is no conflict of interests regarding the publication of this paper.

\section{References}

[1] A. Temiz, N. Terziev, M. Eikenes, and J. Hafren, "Effect of accelerated weathering on surface chemistry of modified wood," Applied Surface Science, vol. 253, no. 12, pp. 5355-5362, 2007.

[2] A. Temiz, G. Alfredsen, U. C. Yildiz et al., "Leaching and decay resistance of alder and pine wood treated with copper based wood preservatives," Maderas: Ciencia y Tecnologia, vol. 16, no. 1, pp. 63-76, 2014.

[3] J. Zhang, D. P. Kamdem, and A. Temiz, "Weathering of copperamine treated wood," Applied Surface Science, vol. 256, no. 3, pp. 842-846, 2009.

[4] A. Temiz, U. C. Yildiz, and T. Nilsson, "Comparison of copper emission rates from wood treated with different preservatives to the environment," Building and Environment, vol. 41, no. 7, pp. 910-914, 2006.

[5] R. Stirling and A. Temiz, "Fungicides and insecticides used in wood preservation," in Deterioration and Protection of Sustainable Biomaterials, American Chemical Society Books, 2014.

[6] W. C. Feist and A. S. Ross, "Performance and durability of finishes on previously coated CCA-treated wood," Forest Products Journal, vol. 45, no. 9, pp. 29-36, 1995.

[7] Y. Xie, A. Krause, C. Mai et al., "Weathering of wood modified with the N-methylol compound 1,3-dimethylol-4,5dihydroxyethyleneurea," Polymer Degradation and Stability, vol. 89, no. 2, pp. 189-199, 2005.

[8] W. C. Fiest and D. N. S. Hon, "The chemistry of solid wood," in Advances in Chemistry Series, No: 207, R. M. Rowell, Ed., pp. 401-451, American Chemical Society, Washington, DC, USA, 1984.

[9] DIN 4768, "Determination of values of surface roughness parameters Ra. Rz. Rmax using electrical contact (stylus) instruments," Concepts and Measuring Conditions, Deutsches Institut für Norming, Berlin, Germany, 1990.

[10] ASTM International, ASTM D 4138, Test Method for Measurement of Dry Film Thickness of Protective, ASTM International, Philadelphia, Pa, USA, 1971.

[11] ASTM International, ASTM D 4541, Test Method for PullOff Strength of Coatings Using Portable, ASTM International, Philadelphia, Pa, USA, 1978.

[12] ISO, ISO 2813, Paints and Varnishes-Determination of Specular Gloss of Non-Metallic Paint Films at 20 Degrees, 60 Degrees 
and 85 Degrees, International Organization for Standardization, Geneva, Switzerland, 1994.

[13] DIN, "Furniture surfaces; behavior at scratches," DIN 68861-4, Deutsches Institut für Norming, Berlin, Germany, 1981.

[14] Deutsches Institut für Norming, DIN 68861-2, Furniture Surfaces; Behavior at Abraison, Deutsches Institut für Norming, Berlin, Germany, 1981.

[15] T. Ozdemir, S. Hiziroglu, and M. Kocapinar, "Adhesion strength of cellulosic varnish coated wood species as function of their surface roughness," Advances in Materials Science and Engineering, vol. 2015, Article ID 525496, 5 pages, 2015.

[16] T. Ozdemir and S. Hiziroglu, "Evaluation of surface quality and adhesion strength of treated solid wood," Journal of Materials Processing Technology, vol. 186, no. 1-3, pp. 311-314, 2007.

[17] I. Aydin, "Effects of borate treatments on the properties of spruce veneers and plywood panels," in Handbook on Borates: Chemistry, Production and Application, chapter 11, pp. 349-366, Nova Science Publishers, New York, NY, USA, 2009.

[18] D. C. Maldas and D. P. Kamdem, "Surface characterization of chromated copper arsenate (CCA)-treated red maple," Journal of Adhesion Science and Technology, vol. 12, no. 7, pp. 763-772, 1998.

[19] I. Aydin and G. Colakoglu, "Variation in surface roughness, wettability and some plywood properties after preservative treatment with boron compounds," Building and Environment, vol. 42, no. 11, pp. 3837-3840, 2007.

[20] A. Temiz, U. C. Yildiz, I. Aydin, M. Eikenes, G. Alfredsen, and G. Çolakoglu, "Surface roughness and color characteristics of wood treated with preservatives after accelerated weathering test," Applied Surface Science, vol. 250, no. 1-4, pp. 35-42, 2005.

[21] E. Zavarin, "Activation of wood surface and nonconventional bonding," in The Chemistry of Solid Wood, R. Rowell, Ed., American Chemical Society (ACS), Washington, DC, USA, 1984.

[22] A. Shakri and M. Seman, "Finishing properties of Acacia mangium, Paraserianthes falcataria and Gmelina arborea timbers: some important parameters," Journal of Tropical Forest Products, vol. 1, no. 1, pp. 83-89, 1995.

[23] Z. Wicks, F. Jones N, and S. Pappas P, Organic Coatings Science and Technology, vol. A of SPE Monograph Series, Willey Interscience, New York, NY, USA, 2nd edition, 1999.

[24] E. Liptáková, J. Kúdela, and O. Paprzycki, "The adhesion of polystyrene to wood," Holz als Roh-und Werkstoff, vol. 49, no. 1, pp. 31-37, 1991.

[25] J. Vitosyto, K. Ukvalbergieno, and G. Keturakis, "The effects of surface roughness on adhesion strength of coated ash (Fraxinus excelsior L.) and Birch (Betula L.) wood," Materials Science, vol. 18, no. 4, pp. 347-351, 2012.

[26] V. R. Gray, "The wettability of wood," Forest Products Journal, vol. 12, pp. 452-461, 1962.

[27] T. F. Shupe, C. Y. Hse, and W. H. Wang, "An investigation of selected factors that influence hardwood wettability," Holzforschung, vol. 55, no. 5, pp. 541-548, 2001.

[28] I. Aydin, "Activation of wood surfaces for glue bonds by mechanical pre-treatment and its effects on some properties of veneer surfaces and plywood panels," Applied Surface Science, vol. 233, no. 1-4, pp. 268-274, 2004.

[29] T. Ozdemir, The investigation of varnishes features at some tree species grown in Turkey [Ph.D. thesis], Karadeniz Technical University, Trabzon, Turkey, 2003. 

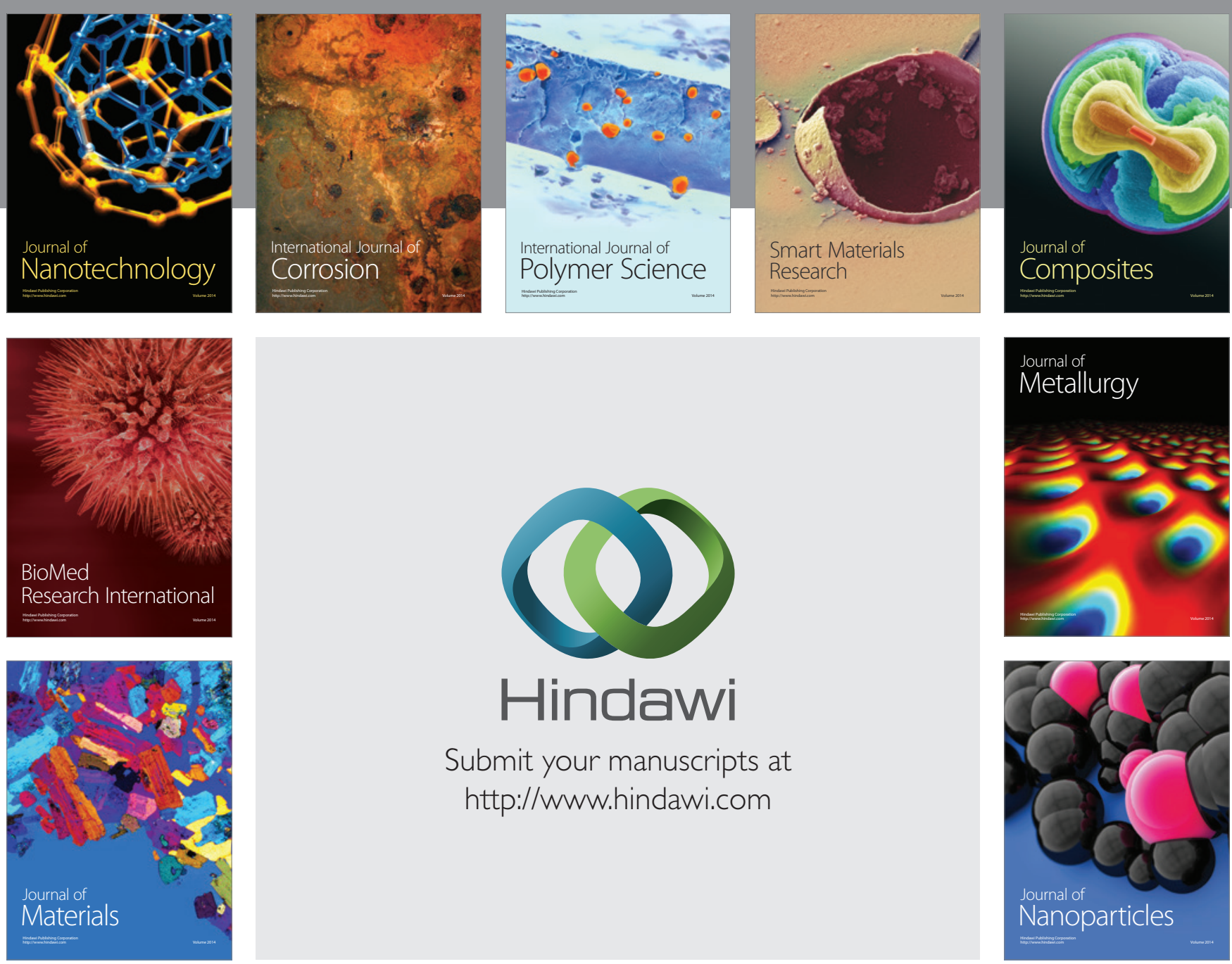

Submit your manuscripts at http://www.hindawi.com
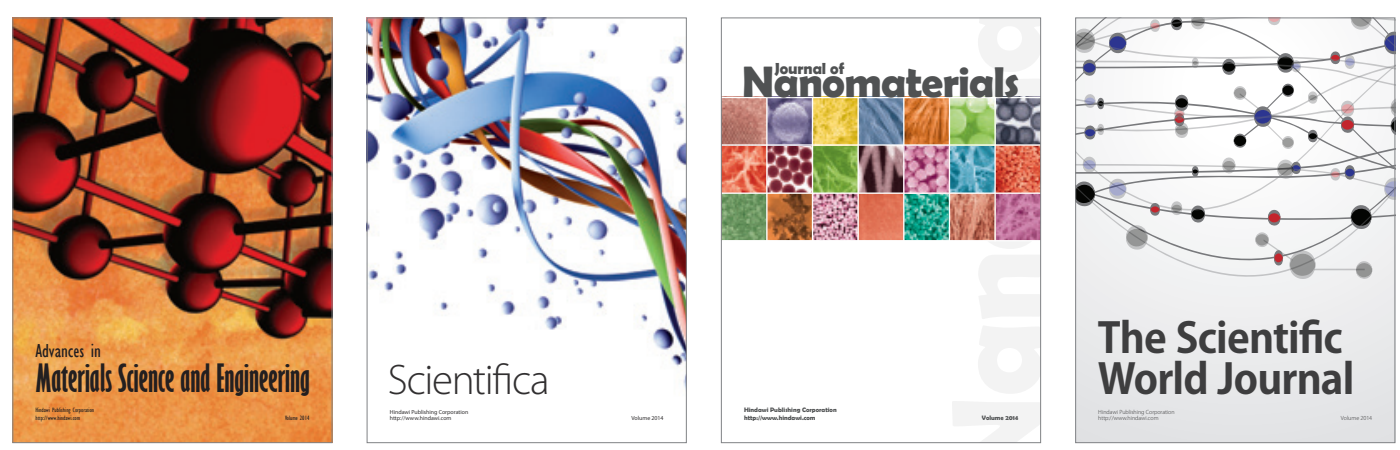

\section{The Scientific World Journal}
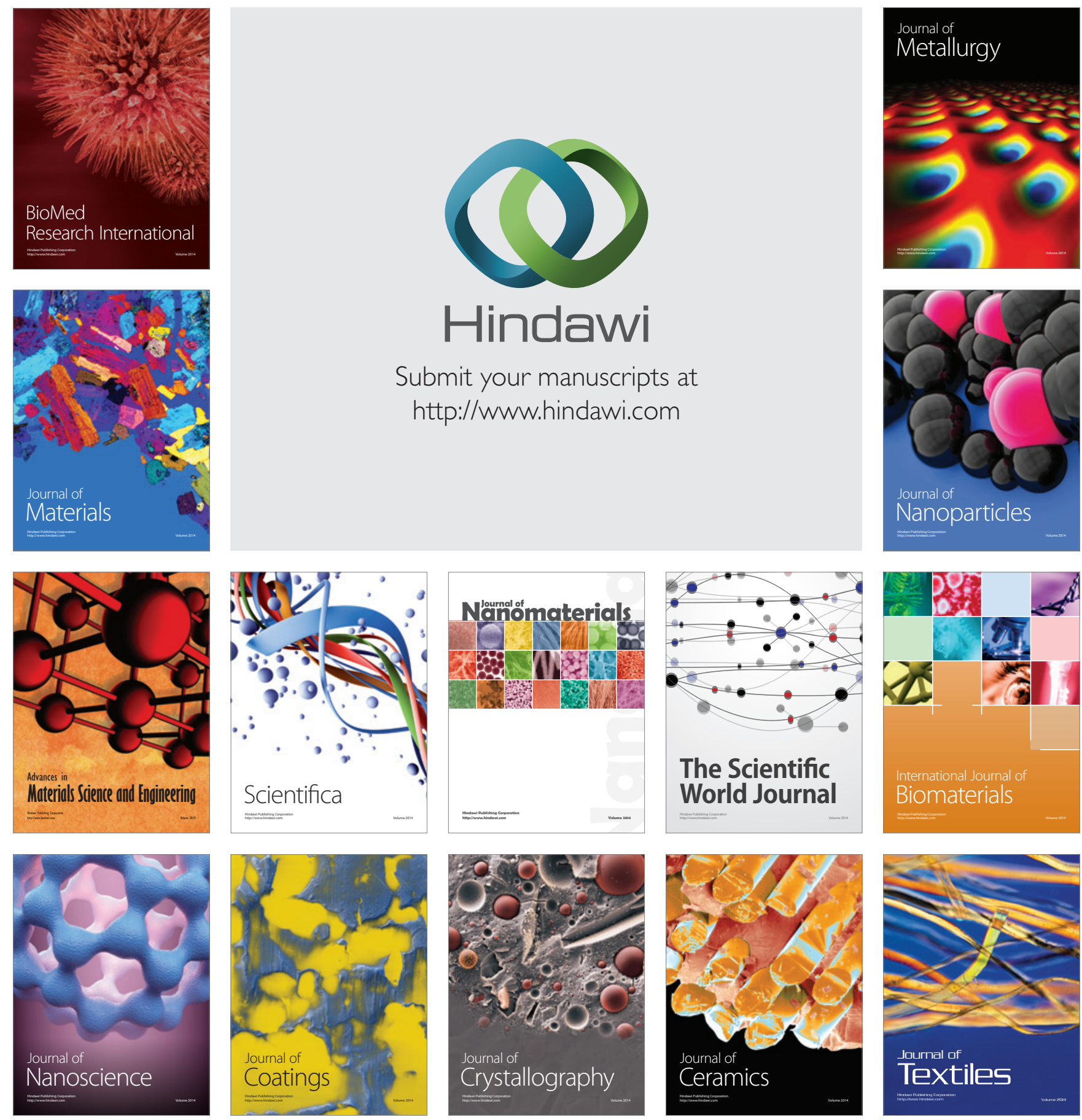